\title{
Munkahelyi pszichoszociális tényezök specifikumai a humán-egészségügyi és szociális ellátás ágazatban dolgozók körében. Komparatív vizsgálat
}

\author{
Psychosocial Work Conditions among Healthcare Workers. A Comparative Study
}

Nistor Katalin ${ }^{1,2}$, Dr. Tóth Gergely3,4, Dr. Szócska Miklós ${ }^{1}$

${ }^{1}$ Semmelweis Egyetem, Egészségügyi Közszolgálati Kar, Egészségügyi Menedzserképző

Központ, ${ }^{2}$ Semmelweis Egyetem Mentális Egészségtudományok Doktori Iskola,

${ }^{3}$ Károli Gáspár Református Egyetem, Bölcsészet- és Társadalomtudományi Kar, ${ }^{4}$ Eötvös

Loránd Kutatási Hálózat, Társadalomtudományi Kutatóközpont, Szociológiai Intézet

Előzetes kutatásai eredményeink szerint a humánegészségügyi és szociális ellátás ágazat a vizsgált 18 KSH ágazat közül a hatodik legnagyobb pszichoszociális stresszterhelésü szektor. Más Európai országokhoz hasonlóan, Magyarországon is elsődleges fontosságú a munkavállalók testi-lelki egészségének védelme és munkaképességének megörzése. Fokozott stresszterhelés esetén a pszichoszociális kockázatok értékelése, megelőzése és csökkentése fontos munkavédelmi intézkedést képez. Ezért keresztmetszeti, nagymintás ( $\mathrm{N}=13104)$, reprezentatív vizsgálatunk fókuszában a humán-egészségügyi és szociális ellátás ágazat COPSOQ II multidimenzionális kérdőívvel vizsgált pszichoszociális tényezőinek elemzése áll. Összességében a két vizsgálati csoport között 18 szignifikáns különbséget azonosítottunk a pszichoszociális tényezők és 3 szignifikáns különbséget az egészségi állapot, jóllét mutatók esetében. A humánegészségügyi és szociális ellátás ágazat munkavállalóinak önbevalláson alapuló eredményei szerint szignifikánsan magasabb szintet értek el az érzelmi megterhelés és a szerepkonfliktus faktoraiban, továbbá több eröszakos magatartásformát tapasztalnak a munkahelyen (erőszakkal való fenyegetés, fizikai eröszak), mint az országos, aktív KSH-szerinti egyéb foglalkozási ágazat munkavállalói.

Based on our previous research, out of the 18 occupational categories classified by the Hungarian Central Statistical Office, healthcare is the 6th most-affected sector by psychosocial stress at work. In Hungary, just as in other European countries, it is crucial to protect and maintain the employee's physical and mental health, respectively their ability to work. In case of increased levels of work-related psychosocial stress, the assessment, prevention, and reduction of stress are highly important occupational safety measures. Therefore, our large sample cross-sectional research $(\mathrm{N}=13104)$, which uses the COPSOQ II multidimensional tool, targets the measurement of psychosocial stress within the healthcare sector. Our study indicates that Hungarian health- care workers are exposed to statistically higher levels of emotional demands and role conflict, and experience more threats of violence and physical violence compared to workers active in other occupational categories in Hungary. In total, we found 18 significant differences in work-related psychosocial factors and 3 significant differences in health and well-being factors.

\section{BEVEZETÉS}

Számos nemzetközi és hazai kutatás rávilágított arra, hogy az egészségügyi ágazatban dolgozó munkavállalók fokozott munkahelyi stresszterhelésnek vannak kitéve. A legföbb stresszorokat többek közt olyan pszichoszociális tényezők képezik, mint a magas mennyiségi elvárások, az alacsony hatáskör, kontroll [1-3] a támadó magatartásformák [3,4], az alacsony megbecsüléshez, jutalmazáshoz társuló munkahelyi elégedetlenség, valamint a munkakörnyezet bizonytalansága [5]. A krónikus munkahelyi stressz következtében az ágazat munkavállalóinak életminőség-mutatói gyengülnek, fokozódhatnak a pszichés és szomatikus tünetek, s mindezek munkahelyi elégedetlenséghez, teljesítménycsökkenéshez [6], illetve fluktuációhoz vezethetnek [5]. A munkahelyi pszichoszociális megterhelésekhez kapcsolódó különböző mentális tünetek és a kiégés mértéke a nemzetközi kutatásokban 10-50\% között alakul [2]. Hazánkban korábbi kutatásaink igazolták [7], hogy a humán-egészségügyi és szociális ellátás ágazat országos viszonylatban a hatodik legnagyobb pszichoszociális stresszterhelésű szektor a vizsgált tizennyolc ágazat közül. Az ágazatban dolgozó munkavállalók önbevalláson alapuló munkahelyi stresszhez köthető egészségiállapot-mutatói igen gyengék. Kiemelendő a magas kiégés, alvászavar, stressz és gyenge önbecsült egészségi állapot, melyek prevalenciája 41,6-58,9\% közötti [3,7,8]. Hazai viszonylatban az alkalmazott munkahelyi stresszt szűrő mérőeszközök egy vagy két elméleti konstruktumra alapozva, két vagy három tényező mentén mérik fel a munkahelyi stresszterhelést. Magyarországi felmérési adatok alapján még nem publikáltak nagymintás, reprezentatív vizs- 
gálati eredményeket, amellyel célzottan erre a vizsgálati területre kifejlesztett multidimenzionális mérőeszközzel [9], huszonnégy munkahelyi pszichoszociális tényező és négy egészségiállapot-mutató mentén hasonlítja össze a humánegészségügyi és szociális ellátás és az egyéb foglalkozási ágazatban dolgozó, aktív munkavállalókat. Jelen tanulmányunkkal egyrészt ezt a hiányt kívánjuk pótolni. Másrészt, az Európai országokhoz hasonlóan, hazánkban is elsődleges fontosságú a munkavállalók testi-lelki egészségének védelme és munkaképességének megőrzése, fokozott stresszterhelés esetén a pszichoszociális kockázatok megelőzése, értékelése és csökkentése, ezért vizsgálatunk az ágazat pszichoszociális helyzetértékelésének feltérképezését célozza.

\section{CÉLKITŰZÉS}

Komparatív vizsgálatunk célkitűzése a humán-egészségügyi és szociális ellátás ágazat pszichoszociális stresszterhelésének és egészségiállapot-mutatóinak elemzése az országos, aktív KSH-szerinti egyéb foglalkozási ágazat munkavállalóinak populációjához viszonyítva.

\section{MÓDSZEREK}

\section{Vizsgálati minta}

Keresztmetszeti kérdőíves vizsgálatunkban az Országos Munkahelyi Stresszfelmérés 2014 során gyűlt adatai szerepelnek. A vizsgálat online alapú kérdőíves felvétellel, kényelmi mintavétellel zajlott. Az N = 13104 főt tartalmazó minta súlyozási eljárás alkalmazása révén, öt dimenzió tekintetében (nem, életkor, iskolai végzettség, foglalkozási ágazat valamint foglalkoztatottság) jól reprezentálja a vonatkozó népesség KSH-szerinti összetételét. Az összehasonlítás alapját a humán- egészségügyi és szociális ellátás ágazat $\mathrm{N}$ súlyozott = 869 fős populációja (a teljes minta 6,63\%-a) továbbá az egyéb foglalkozási ágazatban dolgozók N súlyozott = 12235 fős csoportjai (a teljes minta 93,36\%-a) képezik.

\section{Mérőeszköz}

Az alkalmazott kérdőívcsomagban a demográfiai tényezők esetén a következőket vizsgáltuk: nem, életkor, iskola végzettség, lakóhely, foglalkozási ágazat, a munka jellege. Az ágazati és a munka jellegére vonatkozó kérdések kialakítása során a KSH kategóriákat vettük alapul. A munkahelyi pszichoszociális kockázati tényezők vizsgálatára a nemzetközi kockázatértékelési gyakorlatban széles körben alkalmazott [12,13] és hazánkban a Nemzeti Munkaügyi Hivatal Munkavédelmi és Munkaügyi Igazgatósága által hivatalosan is ajánlott mérőeszközt, a COPSOQ II (Koppenhágai Kérdőív a Munkahelyi Pszihoszociális Tényezőkről II) kérdőívet alkalmaztuk, melyet hazai mintán Nistor K. és munkatársai validáltak [9]. A kutatás során hét dimenziót vizsgáltunk: I. munkahelyi követelmények (3 skála), II. szervezet és munkakör (4 skála), III. együttmüködés és vezetés (7 skála), IV. munkamagánélet egyensúly (2 skála), V. bizalmi légkör (3 skála),
VI. erőszak és zaklatás (4 skála), VII. egészségi állapot, jóllét (4 skála).

\section{Az alkalmazott kérdőív megbízhatósága a vizsgálati mintákon:}

a COPSOQ II kérdőív skáláinak megbízhatósági mutató rendre megfelelőek voltak: a Cronbach-alfa mutatók a súlyozatlan mintán 0,67-0,90 a súlyozott mintán pedig 0,68-0,90 között alakultak.

\section{Statisztikai módszerek}

Az adatok feldolgozását SPSS 20.0 (SPSS Inc., Chicago, Illions, USA) valamint $R$ programmal [14] végeztük el. A vizsgálat során alkalmazott skálák belső megbízhatóságát Cronbach-alfa mutatók kiszámításával ellenőriztük. A Kolmogorov-Smirnov-teszt szerint valamennyi folytonos változó eloszlása szignifikánsan eltért a normáltól, így a továbbiakban ennek figyelembevételével robusztus statisztikai eljárásokat alkalmaztunk többféle megközelítésben, többféle próbát alkalmazva (súlyozatlanul, súlyozva, bootstrap eljárással) a következő három modell szerint:

- Modell: Súlyozatlan = független mintás t-próba, hatásnagyság mutató (Cohen's d)

$\mathrm{N}_{\text {Total }}=13104$ fő, $\mathrm{N}_{\text {Humán-egészségügy }}=1768$,

$\mathrm{N}_{\text {Egyéb foglalkozási ágazatban dolgozók }}=11336$

- Modell: Súlyozott = független mintást- próba, hatásnagyság mutató (Cohen's d)

$$
\mathrm{N}_{\text {Total }}=13104 \text { fő, } \mathrm{N}_{\text {Humán-egészségügy }}=869 \text {, }
$$$$
\mathrm{N}_{\text {Egyéb foglalkozási ágazatban dolgozók }}=12235
$$

- Modell: Inverse Probability bootstrap eljárás = t-próba, $\mathrm{Cl}-\mathrm{k}$. A normalitás sérülésének ellenőrzésére bootstrap eljárást alkalmaztunk, amely az eloszlástól függetlenül képes megbízható robosztus becslést adni [15]. A bootstrap során minden esetében $\mathrm{N}=999$-es ismétlést alkalmaztunk [16]. Végezetül a t-próbák és a bootstrap eljárás eredményeit összevetettük.

\section{Etikai engedély}

„A munkahelyi pszichoszociális kockázatértékelés és a kockázatcsökkentés lehetőségei" c. kutatást a Semmelweis Egyetem Regionális, Intézményi Tudományos és Kutatásetikai Bizottsága hagyta jóvá 2012. december 17- én. TUKEB szám: 195/2012.

\section{Vizsgálati minta}

Elemzéseinket az $\mathrm{N}=13104$ aktív munkavállaló adatai alapján végeztük el. A súlyozott $\mathrm{N}_{\text {Humán-egészségügyi és szociális ellá- }}$ tás ágazat $=869$ fős mintáját $N=682(78,5 \%)$ nő és $187(21,5 \%)$ férfi, míg az $\mathrm{N}_{\text {Egyéb foglalkozási ágazat }}=12235$ fős mintáját pedig $N=5438(44,4 \%)$ nő és $N=6797$ (55,6\%) férfi képezi. $A z$ átlagéletkor az első csoport esetén 43,1 $(S D=10,6)$ a másodinál pedig 40,7 $(S D=11,4)$ év. Az 1. táblázatban ismertetjük a vizsgálatban résztvevő súlyozott vizsgálati minta szociodemográfiai jellemzőit. 


\begin{tabular}{|c|c|c|}
\hline & $\begin{array}{c}\text { Humán } \\
\text { egészségugygi és } \\
\text { szocialis ellátás } \\
\text { àgazat } \\
\text { munkavállalói, } \\
\mathrm{N}(\%)\end{array}$ & $\begin{array}{c}\text { Egyéb (országos, KSH } \\
\text { alapú) foglalkozási } \\
\text { àgazat munkavállaloioi, } \\
\mathrm{N}(\%)\end{array}$ \\
\hline \multicolumn{3}{|l|}{ Életkor } \\
\hline 18-29 & $91(10,4)$ & $2209(18,1)$ \\
\hline $30-39$ & $240(27,6)$ & $3666(30,0)$ \\
\hline $40-49$ & $261(30,0)$ & $3114(25,5)$ \\
\hline $50-59$ & $237(27,3)$ & $2723(22,3)$ \\
\hline 60 év fôlött & $41(4,7)$ & $523(4,3)$ \\
\hline \multicolumn{3}{|l|}{ Lakóhely } \\
\hline Föváros & $215(24,7)$ & $3546(29,0)$ \\
\hline Megyeszzékhely & $131(15,1)$ & $2496(20,4)$ \\
\hline Város & $295(33,9)$ & $4017(32,8)$ \\
\hline Kōzség & $228(26,3)$ & $2177(17,8)$ \\
\hline \multicolumn{3}{|l|}{ Iskolai végzettség } \\
\hline 8 általános vagy kevesebb, mint 8 ăltalános & $28(3,3)$ & $622(5,1)$ \\
\hline Szakmunkásképző & $443(51,0)$ & $4108(33,6)$ \\
\hline Szakközépiskolai érettségi & $17(2,0)$ & $935(7,6)$ \\
\hline Gimnáziumi érettségi & $11(1,3)$ & $634(5,2)$ \\
\hline Szakközzépiskolai êrettségi + OKJ & $81(9,3)$ & $1826(14,9)$ \\
\hline Gimnáziumi érettségi+ OKJ képzés & $50(5,7)$ & $1047(8,6)$ \\
\hline Föiskolai vagy egyetemi diploma & $239(27,5)$ & $3062(25,0)$ \\
\hline \multicolumn{3}{|l|}{ Munka jellege } \\
\hline Segédmunkás vagy betanitott munkás & $115(13,3)$ & $2030(16,6)$ \\
\hline Szakdolgozó & $480(55,2)$ & $3658(29,9)$ \\
\hline Nem diplomás vezetōo, irányitó & $22(2,6)$ & $1254(10,3)$ \\
\hline Szellemi foglalkozású szakember & $114(13,1)$ & $2282(18,6)$ \\
\hline Irodai, ügyviteli dolgozó & $60(6,9)$ & $1923(15,7)$ \\
\hline Diplomás kōzépvezetô̆ & $59(6,8)$ & $683(5,6)$ \\
\hline Diplomás felsövezetö & $18(2,1)$ & $406(3,3)$ \\
\hline \multicolumn{3}{|l|}{ KSH- alapú foglalkozási ágazatok } \\
\hline 1.Mezögazdaság, erdōgazdálkodás, halászat & - & $589(4,8)$ \\
\hline 2. Energia ipar, bányászat, viz-ès hulladékgazdálkodás & . & $293(2,4)$ \\
\hline 3. Feldolgozoipar (gyártás, nyomda) & - & $2591(21,2)$ \\
\hline 4. Épitôipar & - & $837(6,8)$ \\
\hline 5. Kereskedelem, gépjármüjavitás, ingatlanügyek & - & $2019(16,5)$ \\
\hline 6. Szállitás, raktározás & - & $826(6,7)$ \\
\hline $\begin{array}{l}\text { 7. Szálláshely-szolgáltatás, vendéglátás, } \\
\text { idegenforgalom }\end{array}$ & - & $591(4,8)$ \\
\hline 8. IT, telekommunikáció, média, hirkōzlés & - & $376(3,1)$ \\
\hline 9. Pénzúgyi, bizlositási tevékenység & - & $345(2,8)$ \\
\hline 10. Szakmai, tudományos, mûszaki tevékenység & - & $570(4,7)$ \\
\hline $\begin{array}{l}\text { 11. Adminiszzrativ és szolgáltatást támogató } \\
\text { tevékenység }\end{array}$ & - & $485(4,0)$ \\
\hline 12. Kōzigazgatás, védelem, társadalombiżositás & - & $1187(9,7)$ \\
\hline 13.0ktatás & - & $1017(8,3)$ \\
\hline 14.Humán-egészségugugyi, szocialilis ellátás & $869(100)$ & - \\
\hline 15. Mûvészet, szórakoztatás, sport, szabadidô & - & $211(1,7)$ \\
\hline $\begin{array}{l}\text { 16. Egyéb szolgáltatás (érdekképviselet, politika, } \\
\text { egyház) }\end{array}$ & $\cdot$ & $297(2,4)$ \\
\hline
\end{tabular}

\section{1. táblázat}

A súlyozott minta ( $N$ Humán-egészségügy $=869, N$ Egyéb foglalkozási ágazat $=$ 12 235) szociodemográfiai jellemzói. (Forrás: saját szerkesztés)

\section{EREDMÉNYEK}

$A z$ eredmények elemzését két részben ismertetjük. $A z$ elemzés első részében a tanulmány terjedelmére való tekintettel a módszertan bemutatásakor ismertetett három vizsgált modell eredményeit figyelembe véve a legrelevánsabb, súlyozott 2. modellt ismertetjük (lásd 1. és 2. ábrák).

A vizsgálat eredményei szerint:

- A humán-egészségügyi és szociális ellátás ágazat munkavállalóinak önbevalláson alapuló eredményei szerint szignifikánsan magasabb szintet értek el az érzelmi megterhelés és a szerepkonfliktus faktoraiban, továbbá szignifikánsan több erőszakos magatartásforma éri őket az munkahelyen (erőszakkal való fenyegetés, fizikai eröszak) mint az egyéb foglalkozási ágazatban dolgozó csoportot.

- Ugyanakkor a humán-egészségügyi és szociális ellátás ágazatban dolgozók értelmesebb munkáról, több fejlödési lehetőségről, magasabb munkahely iránti elkötelezettségröl, illetve egyértelmübb munkakörről (rendre szignifikánsan magasabb eredmények) számolnak be, mint az egyéb foglalkozási ágazatban dolgozó munkavállalók

- A humán-egészségügyi és szociális ellátás ágazat munkavállalói szignifikánsan alacsonyabb pontszámokat értek el az aktív munkavállalói csoporthoz képest a következő pszichoszociális tényezőkben: hatáskör, kontroll, igazságosság és tisztelet, előreláthatóság, mennyiségi elvárás, munkahelyi elégedettség, vezetés iránti bizalom, munkatársak közötti kölcsönös bizalom, támogatás a felettes részéről, támogatás a munkatársaktól.

- A jelen vizsgálat egészségi állapot, jóllét mutatóinak eredményei szerint a humán- egészségügyi és szociális ellátás munkavállalóinak kiégése és alvászavara szignifikánsan magasabb szintü, az önbecsült egészségi állapotuk pedig szignifikánsan alacsonyabb az egyéb foglalkozási ágazatban dolgozó csoporthoz képest.

Az elemzés második részében a súlyozott 2 . Modell Cohen's d szerinti hatásnagyság mutatóit elemezzük. A COPSOQ II skálák sorrendjét a hatásnagyság mutató csökkenő tendenciája szerint az 3. ábra tartalmazza.

A mutatók elemzése alapján a legjellemzőbb eltérést a két vizsgált csoport között a munkahelyi követelményekhez kapcsolódó érzelmi megterhelés képezi (I. kategória, nagy hatás). Ezt követi a szervezet és munkakör (munka értelmessége, hatáskör, kontroll) továbbá az erőszak és zaklatás (eröszakkal való fenyegetés, fizikai erőszak), az együttműködés és vezetés (szerepkonfliktus, jutalmazás) továbbá a bizalmi légkör (igazságosság és tisztelet) dimenziókhoz kapcsolódó munkahelyi pszichoszociális tényezők (II. kategória). A kapcsolaterősséget kifejező (Cohen's d) értékek szerint szignifikáns, de már kis mértékủ az eltérés a két csoport között a III. kategória az Egészségi állapot, jóllét mutatói - alvászavar, 


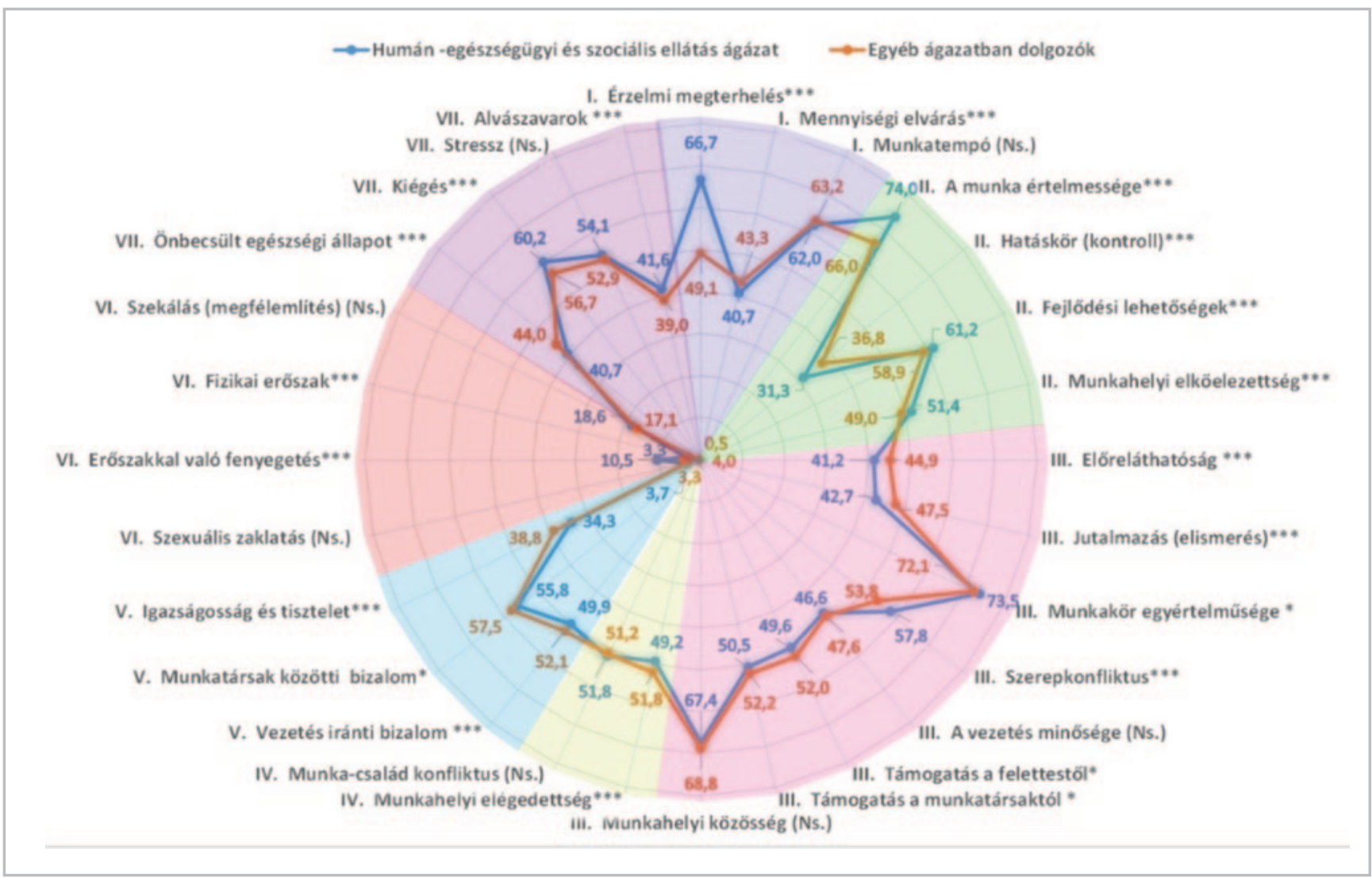

1. ábra

A humán- egészségügyi és szociális ellátás egyéb aktív, KSH-alapú foglalkozási ágazatokhoz viszonyított szignifikáns munkahelyi pszichoszociális tényezóinek és egészségiállapot-mutatóinak ismertetése. Jelmagyarázat: ${ }^{\star} p<0,05 ;{ }^{* * \star} p<0,001 ; \mathrm{Ns}=$ nem szignifikáns; $0=$ minimum, $100=$ maximum COPOSOQ II skálaértékek. COPSOQ II kérdő́iv dimenziók: I. Munkahelyi követelmények, II. Szervezet és munkakör, III. Együttmüködés és vezetés, IV. Munka- magánélet egyensúly, V. Bizalmi légkör, VI. Eröszak és zaklatás, VII. Egészségi állapot, jóllét. (Forrás: saját szerkesztés)

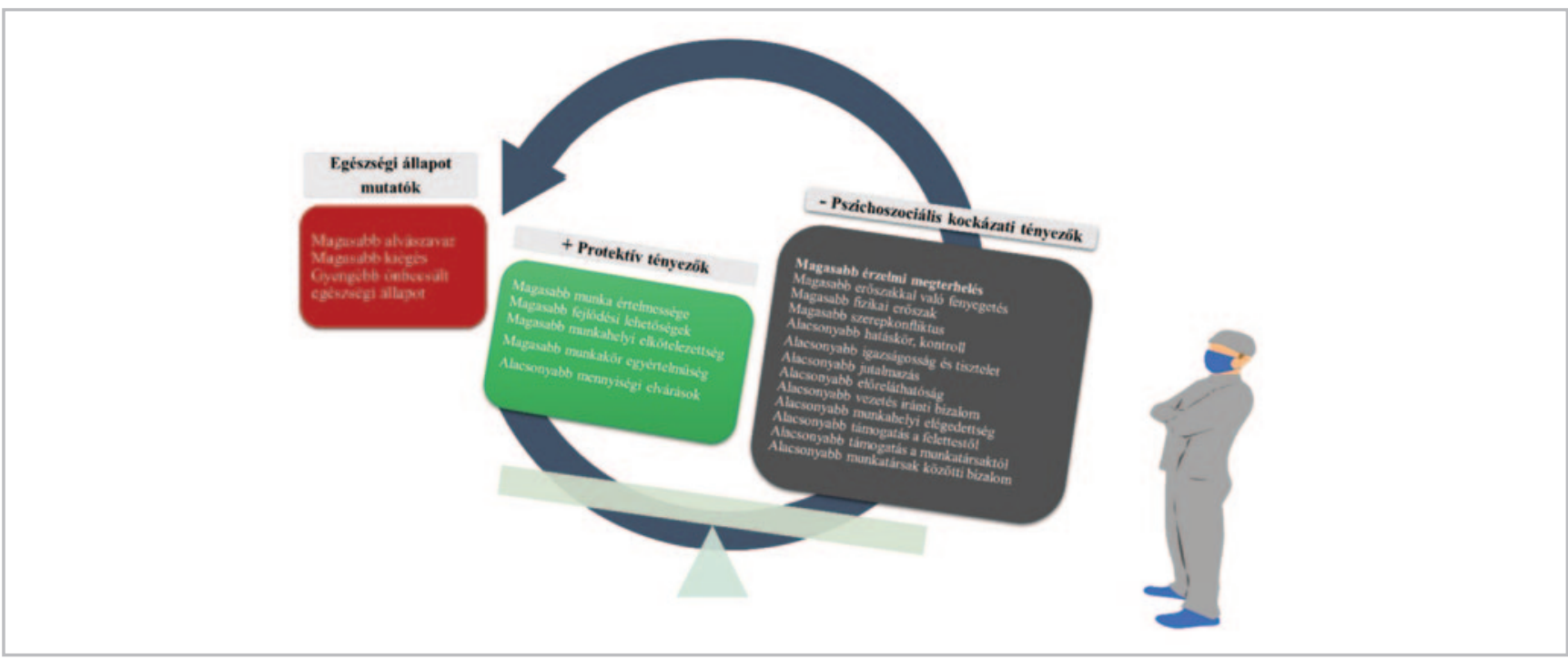

\section{2. ábra}

A humán-egészségügyi és szociális ellátás egyéb aktív, KSH-alapú foglalkozási ágazatokhoz viszonyított föbb pszichoszociális protektív és kockázati tényezői, valamint egészségi állapot, jóllét mutatói. (Forrás: saját szerkesztés)

önbecsült egészségi állapot, kiégés, továbbá az együttmúködés és vezetéshez kapcsolódó egyes tényezők - az elöreláthatóság, támogatás a felettestől, támogatás a munkatár- saktól, illetve olyan szervezeti és munkaköri tényezők, mint a fejlődési lehetőségek és a munkahely iránti elkötelezettség. A munka-magánélet dimenzió munkahelyi elégedettség 


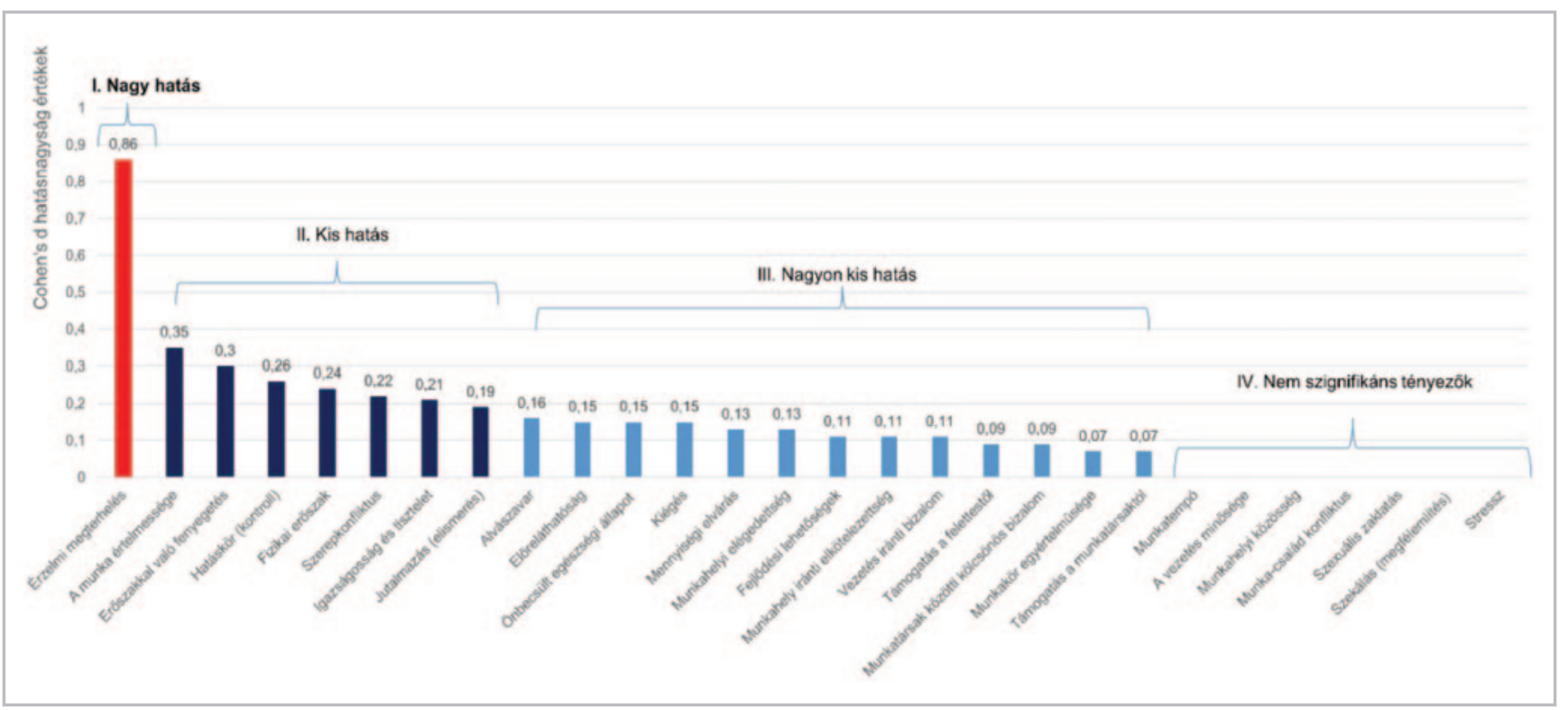

3. ábra

A súlyozott 2. modell hatásnagyság mutatóinak csoportosított értekei a COPSOQ II kérdöívvel mért munkahelyi pszichoszociális tényezök és egészségi állapot mutatók tükrében. (Forrás: saját szerkesztés)

tényezője és a bizalmi légkörhöz kapcsolódó vezetés iránti bizalom szintén ebbe a csoportba tartoznak. A IV. kategória pedig azokat a mutatókat tartalmazza, amelyek esetén nincs szignifikáns különbség a skálák tekintetében a két vizsgált csoport munkavállalói között.

\section{MEGBESZÉLÉS}

Eredményeink alapján a humán-egészségügyi és szociális ellátás munkavállalói csoportja és az egyéb aktív KSH alapú munkavállalói csoport között 18 szignifikáns különbséget azonosítottunk a munkahelyi pszichoszociális tényezők és további 3 szignifikáns különbséget az egészségi állapot, jóllét mutatók esetében.
A kapott eredmények felhívják a figyelmet arra, hogy nemcsak a munkahelyi követelmények, a szervezeti és munkaköri tényezők továbbá a támadó magatartásformák, hanem a horizontális és vertikális interperszonális kapcsolatok (támogatás, bizalmi légkör) és az egészségi állapot, jóllét egyes tényezői (kiégés, alvászavar, önbecsült egészségi állapot) is speciális figyelmet igényelnek a munkaadók és a munkáltatók részéről annak érdekében, hogy a munkahelyi pszichoszociális tényezők optimalizálása megtörténjen a humánegészségügyi és szociális ellátás ágazatban.

A vizsgálat eredményeire alapozva öt specifikus mérföldkövet határozhatunk meg a humán-egészségügyi és szociális ellátás ágazat pszichoszociális kockázatainak csökkentésére és kezelésére vonatkozóan, amelyeket a 4. ábrán részletesen ismertetünk.

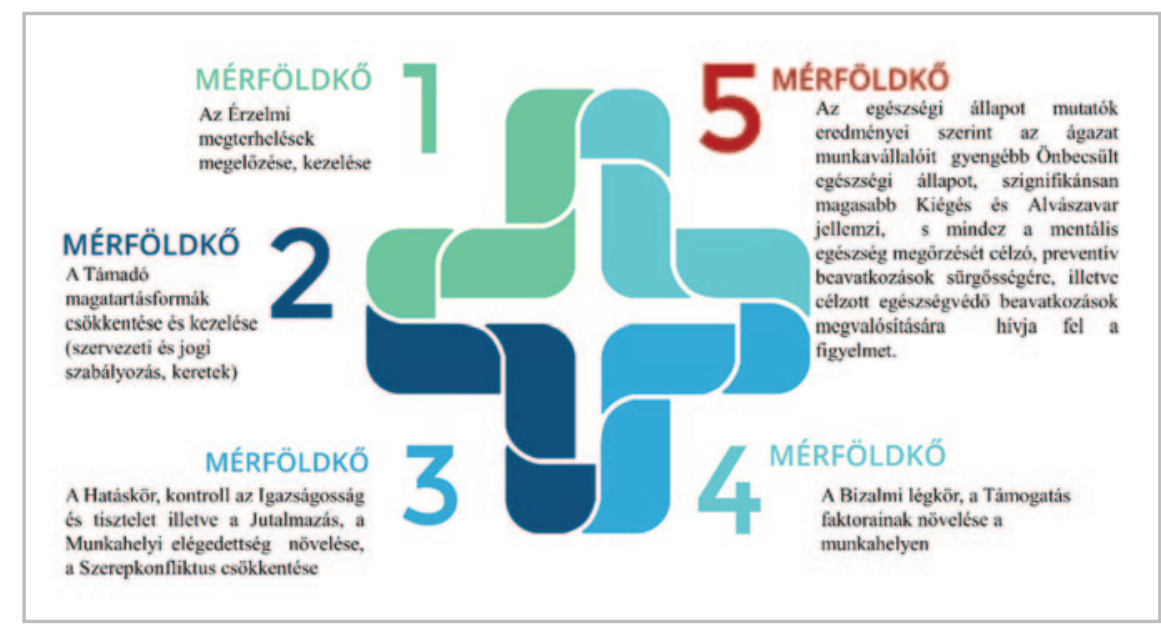

4. ábra

Mérföldkövek a humán-egészségügyi és szociális ellátás ágazat pszichoszociális stresszterhelésének csökkentésére és kezelésére. (Forrás: saját szerkesztés) 


\section{KÖVETKEZTETÉSEK, A VIZSGÁLAT GYAKORLATI HASZNA}

A kutatás egyik erőssége az, hogy eredményeink rendkívül mély betekintést nyújtanak a szervezeti és vezetési kultúrába. Vizsgálatunkkal olyan pszichoszociális tényezők azonosítása vált lehetővé, amelyek gátjai lehetnek az egészséges szervezeti viszonyok kialakulásának, s mindez kihathat az eredményes, minőségi betegellátásra is. A kutatás másik erőssége, hogy validált, multidimenzionális mérőeszközzel [9], nagymintás, a főbb demográfiai csoportokra nézve súlyozás révén reprezentatív vizsgálat keretében kiemelten elemzi a humán-egészségügyi és szociális ellátás ágazat munkahelyi pszichoszociális stresszorait, protektív tényezőit és egészségiállapot-mutatóit az országos, aktív KSH-szerinti egyéb foglalkozási ágazat munkavállalóinak populációjához viszonyítva.

Tágabb perspektívából (munkavédelem, egészségpolitikai változások vezetése) eredményeink egyértelműen rámutatnak a következő tényezőkre:

A rendszeres pszichoszociális kockázatértékelés és kockázatcsökkentés megvalósításának fontosságára a munkahelyeken (lásd még: 1993. évi XCIII. törvény a munkavédelemről).

Egyéni és szervezeti szintű ,,evidence-based”, a mentális egészséget támogató szűrések és beavatkozások, célzott stresszkezelési programok bevezetésének szükségességére - az eredményekre alapozva kiemelten az érzelmi megterheléseket, a támadó magatartásformákat, a szerepkonfliktust, a kiégést és az alvászavarokat csökkentő, az önbecsült egészségi állapotot növelő beavatkozásokra mutatkozik nagy szükség a humán-egészségügyi és szociális ellátás ágazatban.

Hatékony egészségpolitikai változtatások beindítására és megvalósítására, melynek fókuszában az ágazatban dolgozó humán erőforrás, mint érték [10] áll, és amely támogatja az egészséges pszichoszociális munkakörnyezet megteremtésének lehetőségeit.

A kutatás korlátja, hogy az alkalmazott adatfelvételi technológia az eredmények általánosíthatóságát korlátozottá teszi, melyet a mintavételi és adatfelvételi eljárás fejleszté- sével, valamint célirányosan egy longitudinális vizsgálati designnal lehetne potenciálisan fejleszteni. Ugyanakkor a kapott eredmények értékes empirikus vizsgálati adatokkal támasztják alá az MNB 2019 Versenyképességi program 330 pontban ,Egészséges társadalom” koncepciójának 11. pontját, amelyben az átfogó mentális egészségcsomag kidolgozása, a munkahelyi mentális egészségfelmérés és egészségvédelem továbbá a szürési eszközök bevezetése mint stratégia kiemelt szerepet kap [11].

Egészségpolitikai szempontból az ágazatban a legtöbb problémát anyagi szempontból azonosítják. Azonban a hatások ennél sokkal összetettebbek arra vonatkozóan, hogy a munkavállalók és a szervezetek mikor képesek magas teljesítményre és jól működő szervezeti kultúrára. A szervezeti teljesítmény akkor lesz fenntartható, ha hiteles szervezeti kultúrába ágyazottan a munkavállalók testi-lelki egészségvédelme kiemelt prioritást képez (ennek területei: pszichoszociális kockázatértékelés és kockázatcsökkentés, a kiégés kezelését és a stresszkezelési stratégiák növelését célzó programok tudatos bevezetése) és az ezzel kapcsolatos beruházások is megvalósulnak. Ellenkező esetben a szervezeti konfliktusok, valamint a teljesítménycsökkenés a növekvő költségek ellenére is jelen lesznek a szervezetekben. Másrészt a beruházásoknak ki kell terjedniük nemcsak a munkavállalók egészségiállapot-mutatóinak és életminőségének javítására, hanem a szervezeti kultúra, a csoportteljesítmény és a vezetői módszerek területeire is.

\section{KÖSZÖNETNYILVÁNÍTÁS}

A tanulmány az OMMF-11-0104 „Mérőeszköz fejlesztés a munkahelyi pszichoszociális kockázat értékelésére" című pályázat támogatásával készült. Köszönetünket fejezzük ki a Semmelweis Egyetem Magatartástudományi Intézetének, valamint mindazoknak, akik a kérdőívfelvételben szerepet vállaltak. A tanulmány első verziója a Semmelweis Egyetem PhD Tudományos Napok előadás szekciójában hangzott el, 2014-ben. Ennek kapcsán köszönetemet fejezem ki Nistor Anikó Mária közgazdász, data engineernek a statisztikai elemzések során nyújtott segítő közreműködéséért.

\section{IRODALMI HIVATKOZÁSOK}

[1] Wagner A et al.: Healthcare professionals' perspectives on working conditions, leadership, and safety climate: a cross-sectional study. BMC Health Serv Res, 2019. 19(1): p. 53.

https://doi.org/10.1186/s12913-018-3862-7

[2] Tennant C: Work-related stress and depressive disorders. J Psychosom Res, 2001. 51(5): p. 697-704. https://doi.org/10.1016/S0022-3999(01)00255-0

[3] Nistor $\mathrm{K}$ et al.: Psychosocial Work Conditions Among Healthcare Workers: A Comparative Study, in PhD
Scientific Days 2014. 2014, Scientific Programme \& Book of Abstracts Budapest, Hungary p. 94.

[4] Park M. Cho SH, Hong HJ: Prevalence and perpetrators of workplace violence by nursing unit and the relationship between violence and the perceived work environment. J Nurs Scholarsh, 2015. 47(1): p. 87-95. https://doi.org/10.1111/jnu.12112

[5] Mosadeghrad AM, Ferlie E, Rosenberg D: A study of relationship between job stress, quality of working life and turnover intention among hospital employees. 
Health Serv Manage Res, 2011. 24(4): p. 170-81. https://doi.org/10.1258/hsmr.2011.011009

[6] Asante $\mathrm{JO}$ et al.: The relationship between psychosocial risk factors, burnout and quality of life among primary healthcare workers in rural Guangdong province: a cross-sectional study. BMC Health Serv Res, 2019. 19(1): p. 447. https://doi.org/10.1186/s12913-019-4278-8

[7] Stauder A et al.: Quantifying Multiple Work-Related Psychosocial Risk Factors: Proposal for a Composite Indicator Based on the COPSOQ II. Int J Behav Med, 2017. 24(6): p. 915-926.

https://doi.org/10.1007/s12529-017-9651-6

[8] Nistor $\mathrm{K}$ et al.: A depressziós tünetegyüttes kapcsolata szervezeti és munkaköri tényezőkkel ápolók körében. $\mathrm{Az}$ Országos Munkahelyi Stresszfelmérés eredményei. in A pszichiátria jövője. Utazás térben és időben. Magyar Pszichiátriai Társaság XX. Vándorgyűlése. 2016, Psychiatria Hungarica. p. 117.

[9] Nistor K et al.: A Koppenhágai Kérdőív a Munkahelyi Pszichoszociális Tényezőkről II (COPSOQ II) magyar verziójának pszichometriai jellemzői Mentálhigiéné és Pszichoszomatika, 2015. 16(2): p. 179-207. https://doi.org/10.1556/0406.16.2015.2.3

[10] Levi L: Guidance on work-related stress: Spice of life or kiss of death? 2000: Office for Official Publications of the European Communities.
[11] Magyar Nemzeti Bank: Versenyképességi program 330 pontban. 8.fejezet, Egészséges társadalom (2019) https://www.mnb.hu/kiadvanyok/jelentesek/versenykepessegi-program-330 (Letöltés dátuma: 2021. 08. 00. 19:31.)

[12] Pejtersen, J.H., et al., The second version of the Copenhagen Psychosocial Questionnaire. Scand J Public Health, 2010. 38(3 Suppl): p. 8-24. https://doi.org/10.1177/1403494809349858

[13] Kristensen TS et al.: The Copenhagen Psychosocia Questionnaire - a tool for the assessment and improvement of the psychosocial work environment. Scand J Work Environ Health, 2005. 31(6): p. 438-49. https://doi.org/10.5271/sjweh.948

[14] Team RCR: A language and environment for statistical computing. R Foundation for Statistical Computing, Vienna, Austria. 2020;

Available from: https://www.R-project.org/.

[15] Nahorniak $\mathrm{M}$ et al.: Using inverse probability bootstrap sampling to eliminate sample induced bias in modelbased analysis of unequal probability samples. PLoS One, 2015. 10(6): p. e0131765. https://doi.org/10.1371/journal.pone.0131765

[16] Vargha A: Normális vagy? És ha nem? : Statisztikai módszerek nem normális eloszlású változókkal pszichológiai kutatásokban. 2020, Pólya Kiadó

\section{A SZERZŐK BEMUTATÁSA}

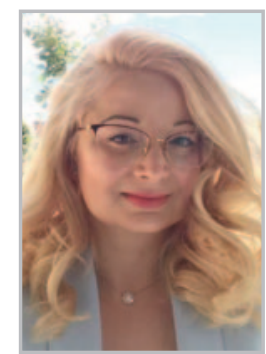

Nistor Katalin, pszichológus, doktorjelölt, okleveles tréner. A Semmelweis Egyetem Egészségügyi Menedzserképző Központ Szociális Vezetőképzésének szenior oktatója. Fő küldetése az egészséges munkahelyek alapelvének gyakorlatba ültetése. Doktori kutatása továbbá publikációi a népegészségügyi jelentőségű munkahelyi stressz és a kiégés jelenségeinek vizsgálatára, a munkahelyi pszichoszociális kockázatértékelés és kockázatcsökkentés opti-

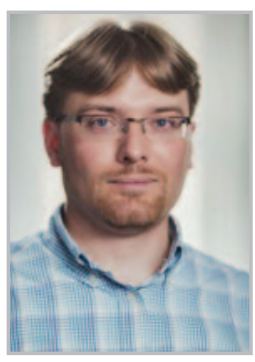

Tóth Gergely PhD szociológus, statisztikus, a Károli Gáspár Egyetem állandó oktatója, a Társadalomtudományi Kutatóközpont munkatársa, valamint a Pharmaproject-Statisztika Bt. ügyvezetője. Több mint 15 éves felsőoktatási oktatói tapasztalattal rendelkezik. Kiemelt oktatási területe a társadalomtudományi módszertanhoz kapcsolódó gyakorlati statisztikai kurzusok, R programozás, illetve az elmúlt 3 évben számos Big Data tárgy oktatását is végzi. malizálásra fókuszálnak. Tizenkétéves felsőoktatási oktatói tapasztattal rendelkezik. Kiemelt oktatási területei: munkahelyi stressz és stresszkezelés, szervezeti magatartás, készség és személyiségfejlesztés, célzott stresszkezelő tréningek. Az elmúlt három évben aktívan részt vesz a vezetői készségfejlesztésben, továbbá intézményi menedzsmentfejlesztő programok kidolgozásában és megvalósításában. Korábban az Országos Tisztifőorvosi Hivatal Munkahelyi és Gazdasági Munkacsoportjának szakértőjeként részt vett a munkahelyi stressz mérésére és kezelésére vonatkozó szakmapolitikai ajánlások kidolgozásában.

Doktori disszertációját a társadalom térbeli aspektusainak a bevett kutatási eljárásokra gyakorolt hatásainak vizsgálata állt, melyet nagymértékben szimulációs eszközök révén tárt fel. További kiemelt kutatási területe interdiszciplináris megközelítésben a statisztikai-módszertani eszközök alkalmazási lehetőségeinek vizsgálata és adoptálása humántudományok, így elsőrendűen társadalomtudományok területén. Ezek közül kiemelkednek a népegészségügyhöz kapcsolódó kutatások, illetőleg olyan innovatív megoldások, mint a szövegbányászat, szimulációk és hálózati elemzések. 


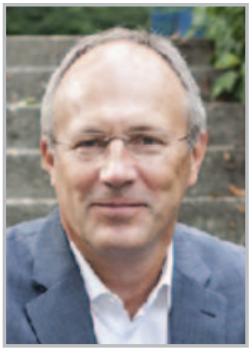

Dr. Szócska Miklós 1989-ben szerzett orvosi diplomát a Semmelweis Egyetemen, ahol a képzés ideje alatt ellenzéki diákvezetőként fordult érdeklődése az egészségügyi menedzsment irányába. Diplomája megszerzését követően kollégáival együtt megalapította az azóta már több mint 20 éves Egészségügyi Menedzserképző Központot, amelynek jelenleg is a vezetője. A menedzserképző fejlesztése során a Harvard Egyetemen szerzett Master of Public Administration diplomát, majd a Semmelweis Egyetemen sikeresen védte meg változtatásmenedzsment témában írt doktori disszertációját. 2010-től egészségügyi államtitkári pozíciót töltött be a politikai ciklus teljes négy éve alatt.
Államtitkárként különösen nagy hangsúlyt fektetett a bizonyítékon alapuló konzultatív egészségpolitika meghonosítására és a gazdasági válság alatt egyre inkább előtérbe kerülő fenntartható egészségügy megalapozására. Legfőbb eredményének mégis a dohányzás visszaszorítása, a kórházi rendszerek központosítása, az e-egészségügy megalapozása, a betegút központú nemzeti egészségügyi szolgálat megteremtése, továbbá a népegészségügyi termékadó bevezetése tekinthető, amely a befolyó összegből biztosította az egészségügyi dolgozók számára a hosszú ideje elmaradt béremelést. Jelenleg az EMK vezetése mellett az EKK dékánja és tagja az SE fenntartói kuratóriumának. Főbb kutatási és oktatási területei a hálózatelemzés, kríziskommunikáció, vezetés- és változtatásmenedzsment, továbbá az adatvezérelt egészségügy és big data megoldások.

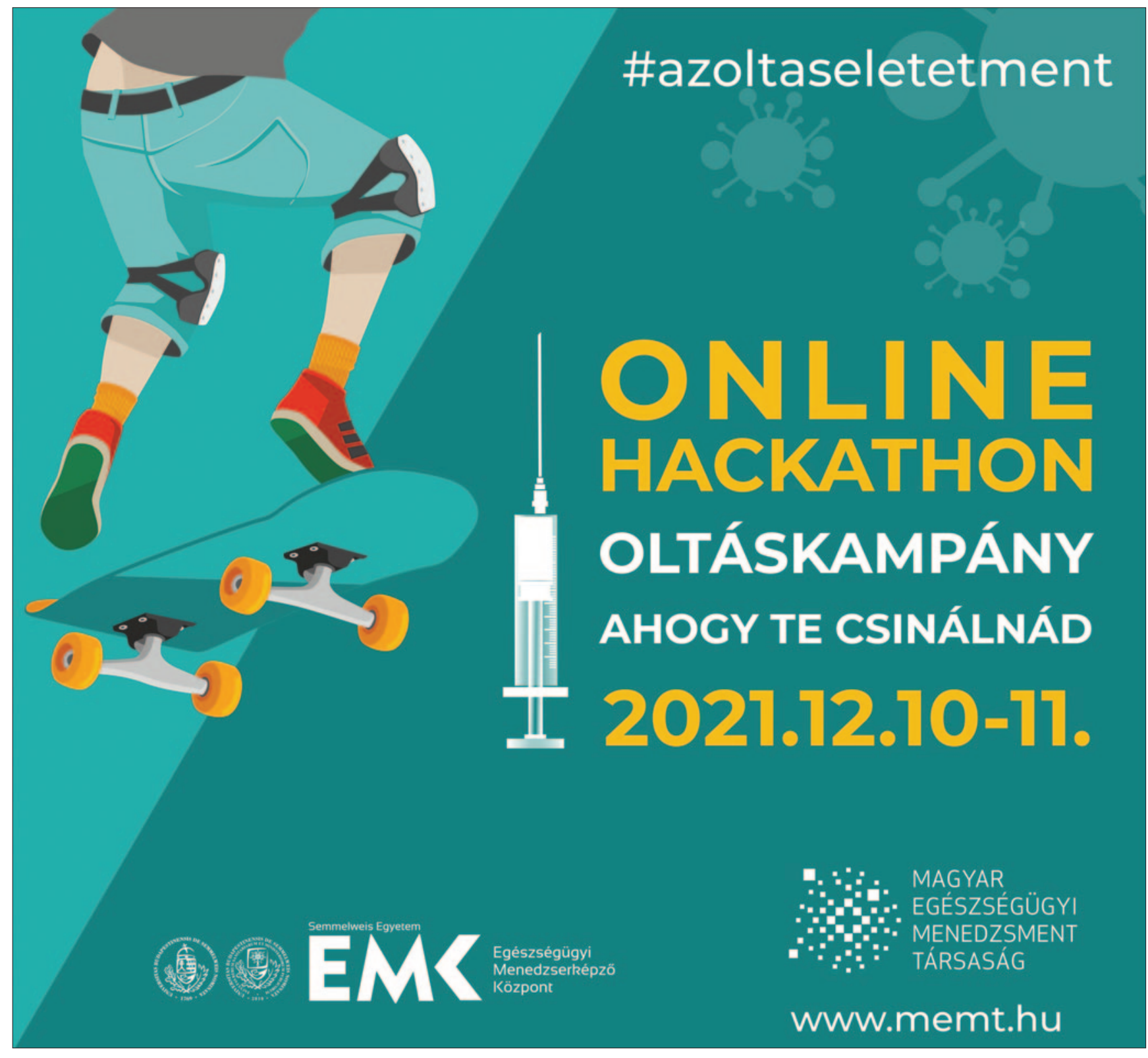

